Hu, H. \& Garimella, U. (2014). iPads for STEM Teachers: A Case Study on Perceived Usefulness, Perceived Proficiency, Intention to Adopt, and Integration in K-12 Instruction. Journal of Educational Technology

\title{
iPads for STEM Teachers: A Case Study on Perceived Usefulness, Perceived Proficiency, Intention to Adopt, and Integration in K-12 Instruction
}

\author{
Haihong Hu \\ University of Central Arkansas \\ Uma Garimella \\ University of Central Arkansas
}

\begin{abstract}
With the rapidly growing popularity of mobile learning and the trend for Bring Your Own Device (BYOD) in the United States, there is an emergent need for up-to-date training on the use of mobile technologies for K-12 STEM teachers. This article will discuss the implementation of and results from an exploratory case study conducted within a summer professional development focused on cultivating teacher readiness for mobile learning on iPads in the STEM fields.
\end{abstract}

Keywords: Mobile learning, iPad, K-12 STEM education, teacher education, technology integration

\section{Introduction}

Tablet PCs are personal computers that use touch-sensitive screens as the major input device.Users interact with the computer through the contact between the surface of the screen and a finger or stylus (Romney, 2011). The use of Tablet PCs and other mobile technologies in educational settings has increased tremendously over the past decade. The iPad is a tablet PC released in January 2010 by the Apple Corporation, and it has $95 \%$ share of the U.S. education tablet market (Sikka, April 25, 2014).The App Store currently hosts over 65,000 educational iPad apps that cover a vast range of subjects for every grade level and learning style (The Apple Corporation, 2014).
According to an October 2012 analysis released by Blackboard and Project Tomorrow (Evans, 2012), 80\% of high-school students and $65 \%$ of middle- school students used smartphones, and $52 \%$ of these students used tablets regularly. The NMC Horizon Report: 2013 K-12 Edition (Johnson, Adams-Becker, Cummins, Estrada, Freeman, \& Ludgate, 2013) predicted mobile learning as one of the two technology trends that would enter into the educational mainstream within the next 12 months. The outlook for educational use of the mobile technology is very positive, and mobile technology usage via the iPad is significant. On October 31st 2011, AppleInsider reported that schools expected to have more iPads than computers in next five years according 
to a survey administered to 25 school district technology directors (Horn, 2011).

Considering the technology requirements from educators'professional organizations (e.g., International Society for Technology in Education) and the popularity of Tablet PCs in education, teachers need to upgrade their knowledge and skills in mobile technologies. The purpose of this exploratory case study was to examine whether a summer technology professional development on using iPads would positively influence K-12 teachers' (a) perceived usefulness of the iPad to support STEM instruction, (b) self-reported proficiency of using the iPad to support student learning in STEM, (c) intention to adopt the iPad, and (d) application of iPad knowledge and skills to the design of a lesson plan.

\section{Positive Effects of Tablet PCs for Education}

Technology is developing exponentially, and tablet computers are one of the most prominently used mobile learning technologies. Tablet computers have been suggested to be useful for students with cognitive impairments (Conley, 2012), for promoting reading fluency (Thoermer \& Williams, 2012), for assisting early struggling readers (Burnside \& Muilenburg, 2012), and for teaching social studies (Berson, Berson, $\&$ Manfra, 2012).

Furthermore, studies demonstrate positive effects of tablet PCs to support student work in STEM areas. In a study (Alemanne, Marty, Douglas, Southerland, Sampson, Kazmer, Clark, \& Mendenhall, 2012), iPad applications and websites were used with elementary students to support their learning about scientific inquiry and to help them participate actively in science education. The preliminary results showed (1) that the students were more actively engaged with their tasks, and (2) that the iPad has a potential to support science teachers in organizing field trips (Alemanne et al, 2012).

In an elementary mathematics methods course, Reins (2007) conducted a study to investigate effective uses of digital ink technology, which refers to writing or drawing directly on the screen of a tablet PC. The findings from a survey indicate positive perceptions regarding the benefits of using the digital ink technology for teaching and learning. Specifically, the participants or preservice K-6 teachers $(\mathrm{N}=40)$ think most positively about (a) the use of colors or other special inking features for coding notes, (b) inking on a projected image makes one feel more engaged in the presentation, and (c) use of projected notes with student inking capabilities.

At the college level, a researcher at the Boston University (Romney, 2011) implemented a longitudinal study to track the impact of tablet PCs on students. He found that students who began their undergraduate mathematics education in Tablet PC classes achieved better performance, accessed the Blackboard course management site more frequently, and were more likely to continue their science and engineering studies than were their peers who took the same course in a non-Tablet PC condition during their first semester of college.

In addition, Perez, Gonzalez, Pitcher, Golding, and Gomez (2012) studied the impact of using the Apple iPad in an undergraduate introductory engineering course, and they found the use of the iPad maintained student's academic performance at a similar level to that of non-iPad classes. There was also a highly positive perceived value of using an iPad in the classroom. The majority of the students perceived learning more in a class that used the technology, and this was found to 
positively influence the classroom atmosphere. Specifically, the student participants attributed increased scores on a comprehension exam to the use of engineering problem solving iPad applications that focused on the topics of unit conversion, area and volume calculations, distance, time, velocity and speed calculations.

Based on the above studies reviewed, tablet PCs were particularly useful for engaging and sustaining students. The digital inking technology was excellent for taking and organizing notes for problem solving and simulations, and the touch-sensitive screen and interaction with fingers allowed even young or special education children to participate in instructional activities integrated with tablets. The developments in mobile learning technology and the emergence of these technologies in schools require a transformation in the skill set of K-12 teachers who will be required to design or deliver education utilizing these new technologies.

\section{Constructive Impact of Technology Professional Development}

To be an effective teacher in a 21st century educational setting, an individual needs to apply the National Educational Technology Standards for Teachers (International Society for Technology in Education [ISTE], 2008), which are the technology "standards for evaluating the skills and knowledge educators need to teach, work and learn in an increasingly connected global and digital society" (para. 1), as he or she (a) designs, implements, and assesses learning experiences to engage students, (b) to enhance professional practice, and (c) to model positively for students, colleagues, and the community. The Association of Mathematics Teacher Educators (AMTE) and the National Science Teachers Association (NSTA) have requested teachers to use technology to support their instruction, enhance student learning, foster mathematical and scientific thinking and communication, and facilitate exploration and deeper conceptual understanding (AMTE, 2006; NSTA, 2008).

In a Congressional Research Service Report, Kuenzi (2008) discussed an emergent concern that the United States was not educating an adequate number of students, teachers, and practitioners in the areas of science, technology, engineering, and mathematics (STEM). The Program for International Student Assessment (PISA) is an assessment coordinated by the Organization for Economic Cooperation and Development (OECD) which compares 15-year-old students' reading, mathematics, and science literacy internationally. The U.S. mathematics literacy average (487) was lower than the OECD average score (496) in 2009 (Fleischman, Hopstock, Pelczar, \& Shelley, 2010). The US was ranked at 18 th in math literacy and at 13th in science literacy among the 34 OECD countries. Based on these findings, there has been a call at the national level to increase students' mathematics and science content knowledge, and technology-based application of content is seen as one means to promote student learning math and science.

Providing effective technology professional development (PD) to STEM teachers was found to have a positive effect on teacher and student learning outcomes (Elliot \& Mikulas, 2012; Martin, Strother, Beglau, Bates, Reitzes, \& McMillan, 2010). Elliot and Mikulas (2012) discovered through a quasiexperimental, pre-post design study comparing growth in Reading and Mathematics skills that students whose teachers participated in technology integration training experienced greater learning gains than students whose teachers did not participate in the online technology integration training. 
Additionally, participating in technology PD was considered helpful for raising teachers' beliefs for teaching STEM areas, technology integration, as well as student achievement. Martin et al. (2010) found that elementary science teachers exhibited significant gains in their science teaching self-efficacy after participating in a long-term, intense (over 100 contact hours annually) instructional technology professional development program. Furthermore, even though only a small portion of the variance was explained, teacher beliefs and the number of hours participating in the professional development program were significant predictors for students' science achievement.

Similarly, Christensen, Knezek, and Tyler-Wood (2014) gathered data from 100200 Hawaii teachers across 40 middle schools in 2010, 2011, 2012 and 2013 to assess the impact of the Hawaii FIRST Pre-Academy, which is a technology-infused PD Program. It was found that STEM disposition and technology integration measures across participants in specific activities were significantly higher than those for teachers who did not participate. The Hawaii FIRST program seems to be successful in fostering positive STEM dispositions in teachers as well as the predilection for technology integration.

Technology PD might work even better if combined with problem-based learning. Walker, Recker, Ye, Robertshaw, Sellers, and Leary (2012) conducted a quasiexperimental study to compare the design of two technology-related teacher professional development (TTPD) experiences to help junior high school science and mathematics teachers create online activities using a set of online learning resources available on the Internet. Both designs demonstrated that teacher participants $(\mathrm{N}=36)$ achieved larger pre-post gains in terms of self-reported knowledge, skills, and technology integration, and teachers in the technology plus Problembased learning (pbl) group had larger gains for self-reported knowledge. Students of tech plus pbl teachers showed significant increases in gain scores for all three outcomes of behavior, knowledge, and attitudes; while students of tech-only teachers showed improved gains only in attitudes.

Therefore, PD on technology might be critical to help the U.S. STEM teachers improve their attitudes in teaching content subjects and enhance their teaching strategies. As a result, this might contribute to raising students' achievement scores in these areas. Based on the positive results from technology PDs, this current study was designed to train teachers on iPad use and integration so as to improve teachers' strategies and attitudes in teaching STEM content, and eventually increase student achievement.

\section{Significance of the Study}

The UCA Institute for STEM Professional Development and Education Research (UCA STEM Institute) is an essential support to the University's mission in science and mathematics teacher education. The Institute provides well-designed STEM educational opportunities through partnerships with local schools, professional development, research, $\mathrm{K}-12$ outreach, and distribution of instructional resources (UCA STEM Institute, n.d.). In the summer of 2012, an informal interview with the Institute's director and the distribution of a needs assessment survey found that due to the wide range of the subject content with limited PD time, as well as learner apprehension with technology, it had not been possible to integrate any training on tablet PCs into STEM teachers' PD as offered by the Institute.

In addition, a high percentage of teachers are not trained or do not know how 
to incorporate mobile devices in teaching. According to a 2013 report by Blackboard and Project Tomorrow (Evans, 2013), 45\% of principals would like new teachers to integrate student-owned mobile devices into lessons, but only $19 \%$ of aspiring teachers stated they knew how to do this. Sharon Robinson, president and CEO of the American Association of Colleges for Teacher Education, also said that most instructors at colleges and universities in the United States and Canada would need training to incorporate mobile learning into their pedagogy successfully (Scott, 2012).

With the growing use of mobile technologies in the U.S. education and the need to educate a new generation of techsavvy K-12 students, the creation and implementation of an iPad PD has been deemed necessary to help STEM teachers in the rural areas of Arkansas to prepare for the technology-based curriculum changes. This professional development will ultimately improve their students' STEM achievements and attitudes.

\section{Methods}

A mixed-method case study was conducted to examine what participants learned from the Professional Development. This study aimed to investigate whether a summer iPad PD would positively influence K-12 teachers': (a) perceived usefulness of the iPad, (b) self-reported proficiency of using the iPad, (c) intention to adopt the iPad, and (d) integration of iPad into the design of a lesson plan. The use of a case study method is appropriate as it provides in-depth exploration that could provide a well-rounded account of the event under investigation (Yin, 2003).

\subsection{Data Sources}

Data were collected from surveys, observation notes, and analyses of lesson plans. The researchers conducted teacher surveys that included both Likert-type and openended questions. This was performed one month before and on the day of the PD. The instruments were adapted from the Pepperdine University's study on the iPad (iPad Research Study, 2011).Quantitative data from Likerttype scales were analyzed using descriptive statistics. Qualitative data from open-ended questions on the surveys, the lesson plans, and observation notes (collected the day of the PD) were analyzed using content analyses. These forms of analyses helped investigate whether participants were able to apply the skills learned to real-world instructional design tasks for integrating the iPads and to triangulate with the quantitative results.

\subsection{Professional Development}

The major instructional goal of the training was effective use of iPad functions and apps and integration of the $\mathrm{iPad}$ in instruction.This PD was designed following the ASSURE model (Smaldino, Lowther, \& Russell, 2012) for technology integration: (a) analyze the learner, (b) state objectives, (c) select media, (d) utilize media, (e) require learner participation, and (f) evaluate and revise. Based on the hands-on, procedural type of learning outcomes developed in this PD, it was decided that the theoretical framework of modeling and "learning by doing" (Dewey, 1897) was appropriate. The following section describes the PD design and implementation process based on the ASSURE model.

5.2.1. Analyze Leaners (Participants). An online questionnaire was used to conduct a needs assessment one month before the professional development. While 13 teachers registered to participate in the $\mathrm{PD}$, only 9 participants 
responded to the pre- and post- assessment and provided the data for the comparison.

The participants included 9 ( 5 female; 4 males) STEM teachers. They were all Caucasian. Only two of them reported that they had used an iPad prior to this PD. Only teachers who completed all the workshop procedures were included as participants in this study, and comparison between the preand post-intervention results were made on exactly the same set of individuals. Please see Table 1 for the participants' profile.

5.2.2. State Standards and Objectives. In the recently revised National Educational Technology Standards for Teachers or NETS-T (ISTE, 2008), there is a significant focus on "engaging students in exploring real-world issues and solving authentic problems using digital tools and resources" (Facilitate and inspire student learning and creativity section, para. 3 ). The NETS-T standards were adopted in the design of this iPad PD for STEM teachers because learners in this training were school teachers, and the iPad is a prominent digital tool or resource that they needed to learn to integrate in K-12 education.

The NETS-T standards matched the most important objectives for the training in that the participants were required to actively engage in observing demonstrations of using the iPad for delivering instruction and exploring general productivity as well as STEM- specific apps. Furthermore, participants were asked to solve real-world instructional problems by creating or modifying a lesson integrating the iPad in a classroom setting using the productivity and STEM specific apps they had just learned. The participants actually experienced what they could do with their

Table 1. Participants' profile

\begin{tabular}{|c|c|c|c|c|c|c|c|}
\hline & Gender & Age & $\begin{array}{l}\text { Level of } \\
\text { educatioln }\end{array}$ & $\begin{array}{l}\text { Subject } \\
\text { area }\end{array}$ & $\begin{array}{l}\text { Grade } \\
\text { level }\end{array}$ & $\begin{array}{l}\text { Teaching } \\
\text { experience } \\
\text { (years) }\end{array}$ & $\begin{array}{l}\text { Self-rated } \\
\text { technology } \\
\text { level }\end{array}$ \\
\hline 1 & Female & $\begin{array}{l}\text { Above } \\
51\end{array}$ & Master's & Science & 4th & 16 & Basic user \\
\hline 2 & Female & $41-50$ & Bachelor's & Science & $\begin{array}{l}\text { 7th \& } \\
\text { 8th }\end{array}$ & 2 & $\begin{array}{l}\text { Intermediate } \\
\text { user }\end{array}$ \\
\hline 3 & Female & $31-40$ & Bachelor's & Science & $7-12$ th & 0 & $\begin{array}{l}\text { Intermediate } \\
\text { user }\end{array}$ \\
\hline 4 & Male & 43 & Master's & $\begin{array}{l}\text { Science, } \\
\text { Math }\end{array}$ & 6 th & 6 & $\begin{array}{l}\text { Intermediate } \\
\text { user }\end{array}$ \\
\hline 5 & Female & $\begin{array}{l}\text { Above } \\
51\end{array}$ & Doctorate & Science & $9-12$ th & 6 & $\begin{array}{l}\text { Intermediate } \\
\text { user }\end{array}$ \\
\hline 6 & Male & $\begin{array}{l}\text { Above } \\
51\end{array}$ & Bachelor's & Math & $9-12$ th & 25 & Basic user \\
\hline 7 & Male & 24 & Bachelor's & Science & $8-12$ th & 1 & Basic user \\
\hline 8 & Female & $41-50$ & Master's & Math & $10-12$ th & 13 & Basic user \\
\hline 9 & Male & $41-50$ & Bachelor's & Science & $9-12$ th & 16 & Basic user \\
\hline
\end{tabular}


students through the modeling and "learning by doing" process embedded in the PD.

\subsubsection{Select and Utilize Media (Instructional}

Materials). The instructional materials used for the professional development included: (a) a Handout (Agenda and resources) shared through the iPad Dropbox app, (b) iPad Integration Lesson Plan Form, (c) a handout of "7 Things You Should Know about iPad" from Educause (2011), and (d) iPad Apps used for demonstration and practices (see Table 2). The instruction was delivered using the Keynote app for presentation through an iPad, a SMARTBoard, and the Internet. While most of the participants brought their own iPads, four of them had to share iPads borrowed from the STEM Institute.

\subsubsection{Require Leaner Participation}

(Procedure). The iPad PD was conducted on the university campus. The session lasted for 6 hours in one day and was implemented through the following steps: (1) self-introductions as participants got to know one another and formed a community of learners; (2) establishing a project baseline with the pre-test using instruments adapted from the Pepperdine University's study (iPad Research Study, 2011); (3) an introduction to iPad in the Classroom through an iPad Keynote presentation and embedded video clips (e.g., iTools: iPads in the Classroom) (MinnetonkaSchools, 2011), a handout of "7 Things You Should Know about iPad" from Educause (2011), and guided discussions; (4) a demonstration (instructor led) of iPad Productivity Tools (e.g., World Facts, ExamBank, Voicethread, Dropbox, Evernote, Flashcards); (5) iPad Productivity Tools Practice; (6) demonstration of iPad STEM Tools (e.g., Mathemagics, iElements, VideoScience); (7) an overview of lessons learned from Pepperdine University's

Table 2. iPad Apps demonstrated and practiced

\begin{tabular}{|c|c|c|}
\hline & Туре of Apps & Specific Title \\
\hline 1 & Productivity Apps: & $\begin{array}{l}\text { World Facts, ExamBank, Voicethread, Dropbox, Flipboard, } \\
\text { Evernote, Flashcards etc. }\end{array}$ \\
\hline 2 & Math Apps: & Algebra Touch, Algebra Pro, Mathemagics, etc. \\
\hline 3 & Science Apps: & $\begin{array}{l}\text { Chemistry: Periodic Table, iElements, VideoScience, } \\
\text { Science } 360 \text {, etc. }\end{array}$ \\
\hline 4 & Engineering Apps & iFixit, iCAD Free \\
\hline
\end{tabular}

iPad Research (adapted version); (8) iPad STEM Tools Practice; (9) lesson plan creation using the iPad Integration Lesson Plan Form (in 30 minutes) and sharing (in 30 minutes) with the community; and (10) PD evaluation and post-test.

5.2.5. Evaluation and Revision. At the end of the professional development, an evaluation survey and a post-test were conducted. The process of analyzing the result data and writing this reflective article embodies the best practices process wherein the researchers evaluate the professional development and revise the design for future endeavors. 


\section{Results \& Findings}

Participants' data on (a) perceived usefulness of iPad for STEM instruction, (b) self-reported proficiency in using iPad for STEM teaching and learning, (c) intention to adopt iPad, and (d) integration of iPad into a lesson plan were collected using paper-pencil questionnaires.

\subsection{Perceived Usefulness of iPad}

The Scale for Perceived Usefulness of iPad consisted of 4 items adapted from the Pepperdine University's Technology FollowUp Survey for the iPad Study (2011). This survey was used to measure how helpful learners thought of iPads for group work, learning new tasks, exploring additional materials, and accessing course information. Participants rated on a 6-point Likert-type scale for each item ranging from 0 (Not Applicable) to 6 (Very Helpful), with 3 equaling "Neutral."
Regarding Perceived Usefulness of iPad, participants reported measurably higher means for learning new tasks, exploring additional materials, and accessing course information at the end than at the beginning of the study. Descriptive Statistics are presented in Table 3.

Participants' responses to some other survey items triangulated with these increases. All participants $(n=9,100 \%)$ considered iPad an effective tool for teaching. Seven participants (Strongly Agree, $\mathrm{n}=1$; Agree, $n=6$ ) believed the iPad encouraged them to interact more than he or she normally would with PD materials. Six participants thought the iPad could provide students with more new information and knowledge; eight thought the iPad could generate more student interest in learning new knowledge; and 5 felt students would be more engaged using the iPads as tools to find and explore information.

When asked "In general, do you feel the iPad can be an effective tool for your teaching?" all $9(100 \%)$ participants selected

Table 3. Descriptive statistics for perceived usefulness

\begin{tabular}{llll}
\hline Item & Mean & $\boldsymbol{N}$ & Std. Deviation \\
\hline newthings_pre & 2.78 & 9 & 1.64 \\
newthings_post & 4.89 & 9 & .33 \\
explore_pre & 2.11 & 9 & 1.62 \\
explore_post & 4.67 & 9 & .50 \\
access_pre & 2.00 & 9 & 1.50 \\
access_post & 4.33 & 9 & .70 \\
\hline
\end{tabular}

"Yes." This is a big improvement from the skeptical responses that participants provided in the needs assessment where $3(33 \%)$ of them selected "Don't know," 2 (22\%) selected "Maybe," and only 4 (44\%) selected "Yes." At the beginning of the study, most participants were not familiar with the tablet functions and apps, did not know for certain what they could do, and how they could help with STEM teaching and learning. Participants' Perceived Usefulness of iPad increased along their learning process during the PD. 


\subsection{Self-Reported Proficiency in Using iPad}

The Scale for Self-Reported Proficiency of Using iPad consisted of 14 items adapted from the Pepperdine University's Survey (2011). This was used to measure how well participants thought they could use each type of apps. Participants rated on a 7-point Likert-type scale for each item ranging from 0 (Never used this app) to 7 (Expert), with 4 equaling "Neutral."

Regarding Self-Reported Proficiency inUsing iPad, participants reported higher means in using Math apps, Science apps, Tech apps, Engineering apps, Note-taking apps, Browser, Dropbox, and YouTube at the end than at the beginning of the study. Descriptive Statistics are provided in Table 4.

Participants' responses to some other survey items supplement these increases. All (100\%) participants (Strongly Agree, $\mathrm{n}=3$; Agree, $n=6$ ) considered they have better ideas about using iPad in teaching. Evidence of participant's self-reported proficiency in using the productivity apps can also be found from the qualitative data in the lesson plans. One

Table 4. Descriptive statistics for self-reported proficiency

\begin{tabular}{llll}
\hline Item & Mean & N & Std. Deviation \\
\hline math_pre & 1.11 & 9 & 1.54 \\
math_post & 3.78 & 9 & .67 \\
science_pre & 1.56 & 9 & 1.59 \\
science_post & 3.44 & 9 & 1.34 \\
tech_pre & 1.33 & 9 & 1.58 \\
tech_post & 2.67 & 9 & 1.58 \\
eng_pre & .89 & 9 & 1.27 \\
eng_post & 2.33 & 9 & 1.80 \\
note_pre & 1.00 & 9 & 1.50 \\
note_post & 3.00 & 9 & 1.87 \\
browser_pre & 2.00 & 9 & 1.73 \\
browser_post & 3.44 & 9 & 1.50 \\
dropbox_pre & 1.11 & 9 & 1.54 \\
dropbox_post & 3.11 & 9 & 1.36 \\
utube_pre & 1.22 & 9 & 1.72 \\
utube_post & 2.89 & 9 & 1.83 \\
\hline
\end{tabular}


of the participants designed a specific activity for note-taking during lesson plan stage. She noted "teaching students how to organize and manage notes" is very important. This participant stated, "I will introduce them to a note taking app like Evernote or Notability. I will spend 30 minutes showing them the app. Then they will explore it on their own." Furthermore, she described the assessment for the activity as "They will email me a copy of their notes." Note-taking is not only an important learning strategy, but also a key part of writing for reflection and problem solving in the science practice. Teaching note-taking facilitates the best practices for STEM instruction (Stohlmann, Moore, \& Roehrig, 2012).

Evidence of participant's proficiency in using the STEM-related apps can also be identified from the lesson plans. When asked to design an iPad activity for the students, $7(77 \%)$ of the 9 participants were able to use a specific title of at least one app. Two $(22 \%)$ of the participants planned activities using two apps and 2 (22\%) other participants designed activities using three apps. One of the participants described that to help students achieve fluency in trigonometry relations and their applications, she was going to use the Flash Cards App to review formula/relationship; the Google Earth App to triangulate information and to calculate plot of land and distance of angle of rotation; and the Screenchomp App for verbally or visually represent solution process to the class. This lesson plan is an excellent representation of the STEM best practices (Stohlmann, Moore, \& Roehrig, 2012) in that it expands the basic hands-on, inquiry-based real-world problem solving to the use of a performance assessment, which requires students to justify their thinking in a cooperative environment through the use of iPad apps.

\subsection{Intention to adopt iPad}

According to the responses to PD evaluation, most (89\%) participants planned to use the iPad in teaching within the coming fall semester $(n=4)$ or in a year $(n=4)$, and $6(67 \%)$ of them felt they would use the apps discussed in teaching soon. Most (89\%) of them (Strongly Agree, $n=3$; Agree, $n=5$ ) felt more confident about using iPad in future teaching. Participants also noted a positive aspect, which might have encouraged the adoption of the iPad as represented by the comment, "I did not have to wait (for) a computer lab." However, participants reported their concerns regarding some of the logistic or contextual issues of using iPad in their classroom, demonstrated by the following responses, "We do not currently have wifi, so this year it may (only) be used for individual or small group," "I really want to know how I can get the school on board so I can use iPad in the classroom. Just starting out first year teacher this fall," and "Without close supervision, students resort to playing non-educational games or visiting social networking sites."

\subsection{Integration of iPad in Instruction}

Based on learners' iPad Integration Lesson Plan, these 9 teachers will have an impact on at least 706 students. They would also encompass a wide range of disciplines from courses such as Science, Math, Social Studies, Physical Science, Physics, Chemistry, Biology, Trigonometry/Pre-calculus, Algebra II and Pre-Calculus, Algebra I, and Environmental Science.

6.4.1. Shift in Pedagogy. In the 30 minutes provided, participants created lesson plans imitating the teaching methods experienced during the professional development including real-world modeling and "learning by doing." Seven (77.8\%) of the 9 participants reported that they originally used traditional 
lecturing as the major strategy for teaching over $50 \%$ of their course; however, during the workshop they planned student-centered activities using the iPad and moved away from the pure instructor-directed approach. This is an encouraging change consistent with the requirements from NETS-T (ISTE, 2008) in that these participants were able to design active learning experiences to engage students and they would be able to provide opportunities for students to experiment and solve authentic problems using the digital tool of iPad and relevant resources. Some of the excerpts from the participants' lesson plans representing this shift in mindset are the following quotes:

- I know I need to get away from lecture and go to more hands-on. I liked the planet app for when we studied the solar system.

- Method- Lecture, videos, toys. Students will design (their) own roller coaster (preAP students will build coasters).

- The students can do the simulation to actually see how gas law works.

This exciting change can also be verified through participants' responses in the evaluation of the PD. For opinions toward each of the major professional development activities, the participants answered 2 researcher-designed questions on a 5-point Likert-type scale. These questions are: (1) I think going through ... has helped me achieve better learning results, and (2) I think going through ... has helped me become more confident in my knowledge about using iPad for teaching and learning. The descriptive statistics for learners' attitude indicate that even though the overall response to the professional development was positive, participants still marginally preferred more traditional, passive style of instructional activities, such as instructional demonstration $(\mathrm{M}=4.1$ for both learning and confidence) and in-class discussion $(\mathrm{M}=4.1$ for learning and $\mathrm{M}=4.0$ for confidence), than the handson approach of iPad App practices $(\mathrm{M}=3.9$ for learning and $\mathrm{M}=3.8$ for confidence) for the training. This could have been a combined effect of their age, the education they received, and the teaching and learning style that they have developed over the years. However, this has made the situation even more significant when these participants started planning for hands-on and active iPad integration STEM lessons for their own students.

\subsubsection{Learner-Centered, Active Strategies.} In their lesson plans, participants designed a great variety of active, learner-centered activities to take advantage of the unique functions and features of iPad apps for STEM instruction. One participant described the use of the iPad for collaborative learning through a specific example, "lecture with class discussion \& pictures on SMARTBoard, students read lessons with partner and answer questions. Then small group gives a presentation on a particular planet using internet and SMARTBoard." In this manner, K-12 students learn not only science and math content, but also team work.

Some pedagogical designs provided by the participants reflected their use of active hands-on instructional approaches taking advantage of iPad's technical features of touch-sensitive screen and human computer interaction for digital manipulatives. For instance, "Using froguts or frog dissection (simulation) as a prelab activity," "Having student pull up information on the person (Mathematicians), who comes up with how to find the solution," and "The iPad has several different apps with a 3-D model of the cell. This is helpful so students can see a good real life model" are some examples. These approaches allow students to connect 
abstract concepts or solutions to the actual Mathematician, cell, or animal, making Math and Science more concrete and relevant to the students. As a result, such connections can help increase learner interest and motivation (Keller, 2010), which is an essential component of effective STEM instruction (National Research Council, 2011).

Participant designed iPad activities to provide instructional content using multiple modes of presentation, and their lessons showed that they were trying to utilize iPad's strengths for visual representation of knowledge and concepts. The following ideas are excellent demonstrations of designing instruction for multiple learning styles. Two participants noted, "If a student is failing to understand the concept, then perhaps they can understand the information from another source," and "Use Statistics Visualizer for calculating chi-square results."

In their lesson plans, participants not only identified specific outcomes that they could teach integrating the iPad, but also designed performance-based assessments that measured student achievement. Some of them planned to use the Flash Cards App for review of formulas or concepts and the Socrative App for giving quizzes. This demonstrates that the participants' lesson plans are in line with the requirements for clearly-defined goals and assessments, which is one of the key criteria for best practices in K-12 STEM education ((Bayer Corporation, 2010; Stohlmann, Moore, \& Roehrig, 2012). Some of the other assessments planned by the participants were:

- Designed coaster with labels indicating energy conversion and laws (after using the Coaster Physics app)

- Explanation of gas laws (after using the Gas Law simulation)
- Lab reports (for Frog Dissection) and Visual assessment (for Statistics Visualizer)

Based on data gleaned from the lesson plans, participants clearly intended to use the iPad as a tool to engage students, help students understand concepts through multiple representations, and test students with realworld applications of knowledge and concepts. These approaches are aligned with best practices in the research regarding STEM instruction and assessment, which focus on inquiry-based experiential curriculum that encourages authentic problem solving (Bayer Corporation, 2010: National Research Council, 2011;Stohlmann, Moore, \& Roehrig, 2012).

\section{Discussion}

Overall, participants in this study positively embraced the iPad as a useful and effective tool for STEM teaching and learning, they improved measurably in their perceived proficiency for using the iPad, and were able to apply their knowledge and skills in the design of a lesson plan to actively engage students in learning activities and assessments.

As to Perceived Usefulness of iPad, participants from this study reported higher means for learning new things, exploring additional materials, and accessing course information at the end than at the beginning of the study. This is comparable to the findings from a case study of Mobile Learning Pilot Project in K-12 schools by Chou, Block, and Jesness (2012). They found that teachers who participated in an iPad PD and then completed a one-to-one implementation felt that the tablet was useful for improving information search and literacy, and for enhancing teaching with updated information.

Concerning Self-Reported Proficiency in Using iPad productivity tools, participants 
reported higher means in using Note-taking apps, Browser, and Dropbox at the end than the beginning of the study. This is consistent with the findings from Kearney and Maher's (2013) study that the use of iPad could enhance the pre-service teachers' productivity and efficiency. This finding also confirms the results from the study on the iPad's support to elementary students' learning about scientific inquiry in that the iPad has a potential to support science teachers in organizing field trips (Alemanne et al., 2012). In view of SelfReported Proficiency in Using iPad STEMrelated apps, participants reported higher means in using Math apps, Science apps, Tech apps, and Engineering apps, at the end than at the beginning of the study. This is similar to the improvement in pre-service STEM teachers' perceived Technological Pedagogical Content Knowledge (TPACK) from Mobile learning using iPads (Kearney \& Maher, 2013).

Regarding intention to adopt, most participants were very positive about using the iPad in teaching and felt they would use the apps discussed in the near future. The Technology Adoption Model (TAM) (Davis, 1989) might help us understand this result more clearly. According to the Technology Adoption Model (TAM), perceived usefulness and perceived ease of use are significantly correlated with current and future usage of information technology (Davis, 1989). This theory might explain why the perceived usefulness in this current study could be a major contributor to Tablet PC acceptance (Moran, Hawkes, \& Gayar, 2010) and this might have brought about the high percentage of participants $(88.9 \%)$ indicating their intention to adopt iPad within one year. On the other hand, most of the participants felt more confident about using iPad in future teaching; this was an indicator of their self-efficacy. According to the TAM, confidence in using the
iPad might have acted as a causal antecedent to perceived usefulness in this current study. Besides the positive feedback, participants reported some concerns regarding logistic or contextual issues, which can be considered the external variables in TAM, of adopting iPad. According to Ertmer (1999), these might become barriers to iPad integration if they do not receive sufficient attention soon. Even though this PD is effective in raising participants' beliefs about iPad and confidence in using it, the lack of resources (e.g., wifi) and support from administrators (e.g., in purchasing iPads or in making policies for students to use iPads appropriately) can cause interest in adopting mobile technology to dwindle quickly.

Effective STEM instruction is characterized as capitalizing on students' interest and experience and providing experience to engage students in the practice of science (National Research Council, 2011). The examples of activities from the lesson plans illustrate that participants were wellaware of and appropriately utilizing the touch screen and multimedia functions of the iPad for stimulating and sustaining learner interest and offering students opportunities for collaborative discussion and interaction, which is a normal process for science discovery.

Participants' perceived success in learning and integrating the iPad apps could have been attributed to how apps were selected. The apps were evaluated and tested according to the ASSURE model for technology integration and designed into activities for demonstration and practices. Specifically, they were evaluated using Selection Rubrics for Computer Software and Multimedia (Smaldino, Lowther, \& Russell, 2012) on alignment with standards, accuracy and currency of information, ageappropriateness of language, engagement, technical quality, ease of use, bias free, user directions, variety of media, and multisensory 
experience based on the learner characteristics of this participant group (middle age, mostly experienced with teaching, mixed subject areas and proficiency with technology) in the PD. Also, apps were selected to accommodate relevant subject areas of all participants such as Science, Math, Physics, Chemistry, Biology, etc., and to help participants overcome fear, and to prepare teachers with a foundation to start their own exploration or practice using the iPad for instructor presentation or one-toone implementation.

The focus of the apps selected for this PD was on those that encouraged student inquiry, engagement, and collaboration.These apps were particularly effective for hands-on, trial and error, experimentation, simulation, or manipulation (e.g., Frog Dissection, Gas Laws HD Lite) to allow students to touch, swap, move things around, see the cause and effect, figure out the concepts or making the connection between the abstract and concrete (e.g., 3D Cell Simulation and Stain Tool, K12 Periodic Table of the Elements), and obtain feedback immediately (e.g., Socrative, Flashcards).

The visual and audio functions of the iPad apps used in this PD can engage students (e.g.,VideoScience, Science 360), allow students to learn through multiple channels, create things (e.g., Coaster Physics, iCAD Free), communicate and collaborate (e.g, Dropbox, Evernote), explore, research (e.g., Mathemagics, World Facts), and problem solve (e.g., Algebra Pro).This study confirms Chou, Block , and Jesness' (2012) findings in that iPad apps can engage learners actively in student-centered activities, and there are more varieties of apps than on the computers for student-centered activities. They are valuable for the Engage, Explore, Explain, and Extend processes in 4Ex2 lessons for STEM instruction and best practice (Marshall, Horton, \& Smart, 2009).
This Professional Development can be considered effective in improving Perceived Usefulness of iPad and Self-Reported Proficiency in Using iPad because it went through a rigorous instructional design process and is aligned with a framework by Martin et al. (2010) for connecting instructional technology PD to teacher and student outcomes. This connection encompassed: (a) modeling instruction(the iPad demonstration modeled the instructional techniques that were presented); (b) community building (participants were engaged in activities such as self-introduction, discussions, and lesson plan sharing that supported collaborative learning and community building); (c) technology utilization (the target technology was used to support the instruction and participants' practice with the iPad Apps); and (d) connection to practice (the PD content was applied in the lesson plan process and associated with participants' regular instructional standards and objectives).

\subsection{Limitations of the study}

This study's results may not reliably apply to other populations due to the small sample size, the nature of voluntary summer professional development, and the preliminary stage of iPad empirical research. However, the project provides valuable information to consider in the instructional design of future technology and pedagogy PDs.

\section{Conclusion}

In the future, extended duration for the professional development through a blended learning format to one week or one semester is needed to provide teachers with more exposure to and immersion in mobile technology. Additional recommendations include sustained technical support and peer mentoring so that participants will be able to practice with the 
iPad apps more and for an extended period of time. At some point, the PD providers hope to arrange for all participants have iPads with Internet access and teach participants how to download the apps during the training session. More empirical evidence of whether using the iPad works is required to determine best practices for integrating STEM apps into the classroom. Additionally, expanding the participant pool and tailoring workshops for high school versus elementary teachers is also recommended. Finally, a blog or a wiki could be established as a way to contain training materials, support the development of a learning community, and share "just-in-time" information (Britten, 2011).

Overall, this iPad professional development for K-12 STEM teachers was a positive and productive experience for participants allowing them to upgrade their knowledge and skills in teaching and learning, experiment with emerging mobile technologies, and nurture their readiness for mobile learning in the STEM fields. They had active experience with the iPads through "learning by doing" and were able to design hands-on lesson plans integrating the iPad in inquiry-based, cooperative learning activities and assessments to achieve STEM-related outcomes. The participants have learned to use the iPad as a support for best practices in STEM instruction and assessment.

\section{References}

Alemanne, N. D., Marty, P. F., Douglas, I., Southerland, S. A., Sampson, V., Kazmer, M. M., Clark, A., \& Mendenhall, A. (2012, October). Habitat Tracker: Engaging students with scientific inquiry through technology and curriculum support. Poster presented at the 75th Annual Meeting of the American Society for Information Science \& Technology (ASIS\&T 2012), Baltimore, MD.

Association of Mathematics Teacher Educators. (2006). Preparing teachers to use technology to enhance the learning of mathematics: A position of the Association of Mathematics Teacher Educators. Retrieved from http://www. amte.net/sites/all/themes/amte/resources/ AMTETechnologyPositionStatement.pdf

Bayer Corporation. (2010). Planting the seeds for a diverse U.S. STEM pipeline: A compendium of best practice K-12 STEM education programs. Retrieved http:// www.bayerus.com/msms/web_docs/ compendium.pdf

Berson, I. R., Berson, M. J., \&Manfra, M. M. (2012). Touch, Type, and Transform: iPads in the Social Studies Classroom. Social Education, 76(2), 88-91.

Britten, J. (2011). Using teacher inquiry about, and exposure to, mobile technologies as a means to advance student engagement. In M. Koehler \& P. Mishra (Eds.), Proceedings of Society for Information Technology \& Teacher Education International Conference 2011 (pp. 23662371). Chesapeake, VA: AACE.Retrieved from: http://www.editlib.org/p/36662.

Burnside, R., \& Muilenburg, L. (2012, June).Using the iPad to support early struggling readers. In World Conference on Educational Multimedia, Hypermedia and Telecommunications (Vol. 2012, No. 1, pp. 2374-2375). 
Chou, C.C., Block, L., \& Jesness, R. (2012).A case study of mobile learning pilot project in K-12 schools. Journal of Educational Technology Development and Exchange, 5(2), 11-26.

Christensen, R., Knezek, G., \& Tyler-Wood, T. (2014). Fostering technology integration skills and positive STEM dispositions in Hawaii middle school science and technology teachers. In M. Searson \& M. Ochoa (Eds.), Proceedings of Society for Information Technology \& Teacher Education International Conference 2014 (pp. 1386-1393). Chesapeake, VA: AACE. Retrieved from http://www.editlib.org/ $\mathrm{p} / 130960$.

Conley, J. (2012, March). Can the iPad Address the Needs of Students with Cognitive Impairments by Meeting IEP Goals? In Society for Information Technology \& Teacher Education International Conference (Vol. 2012, No. 1, pp. 3986-3990).

Davis, F. (1989).Perceived usefulness, perceived ease of use, and user acceptance of information technology. MIS Quarterly, 13(3), 319-340.

Dewey, J. (1897). My pedagogic creed. School Journal, 54, 77-80.

Educause Learning Initiative. (2011). 7 Things you should know about iPad apps for learning. Retrieved from: http://net. educause.edu/ir/library/pdf/eli7069.pdf

Elliot, S., \& Mikulas, C. (2012).Improving student learning through teacher technology training: A study of the effectiveness of technology integration training on student achievement. In P. Resta (Ed.), Proceedings of Society for Information Technology \& Teacher Education International Conference 2012 (pp. 1759-1766). Chesapeake, VA: AACE. Retrieved from http://www.editlib.org/ $\mathrm{p} / 39842$.

Ertmer, P. (1999). Addressing first- and second-order barriers to change: Strategies for technology implementation. Educational Technology Research and Development, 47(4), 47-61.

Evans, J. (2012). Personalized learning: New speak up findings on students, parents, and educator aspirations for mobile learning. Retrieved from: http://www.tomorrow. org/speakup/NewSpeakFindings2012 pres.html.

Evans, J. (2013). Learning in the 21st Century: Digital experiences and expectations of tomorrow's teachers. Retrieved from:http://www.tomorrow.org/speakup/ tomorrowsteachers report2013 pres.html.

Fleischman, H.L., Hopstock, P.J., Pelczar, M.P., \& Shelley, B.E. (2010). Highlights from PISA 2009: Performance of U.S. 15-Year-Old students in reading, mathematics, and science literacy in an international context (NCES 2011004). U.S. Department of Education, National Center for Education Statistics. Washington, DC: U.S. Government Printing Office.

Horn, L. (2011). Schools expect to have more iPads than computers in next 5 years. Retrieved from http://appleinsider.com/ $\operatorname{articles} / 11 / 10 / 31 / \mathrm{schools}$ _expect_to have more ipads than_computers in next_5 years.html.

International Society for Technology in Education (ISTE). (2008) National Educational Technology Standards for Teachers (NETS•T). Retrieved from: http://www.iste.org/standards/standardsfor-teachers.

iPad Research Study. (2011). Retrieved from:http:/community.pepperdine.edu/it/ tools/ipad/research/ ).

Johnson, L., Adams-Becker, S., Cummins, M., Estrada V., Freeman, A., \& Ludgate, H. (2013). NMC Horizon Report: 2013 K-12 Edition. Austin, TX: The New Media Consortium. 
Kearney, M., \& Maher, D. (2013). Mobile learning in math teacher education: Using iPads to support pre-service teachers' professional development. Australian Educational Computing, 27(3), 76-84.

Keller, J. M. (2010). Motivational design for learning and performance: The ARCS model approach. New York: Springer.

Kuenzi, J. J. (2008). Science, technology, engineering, and mathematics (STEM) education: background, federal policy, and legislative action. Congressional Research Service Reports. Paper 35. Retrieved from: http://digitalcommons.unl.edu/ crsdocs $/ 35$

Marshall, J. C., Horton, B., \& Smart, J. (2009). $4 \mathrm{E} \times 2$ instructional model: Uniting three learning constructs to improve praxis in science and mathematics classrooms. Journal of Science Teacher Education, 20(6), 501-516.

Martin, W., Strother, S., Beglau, M., Bates, L., Reitzes, T., \& McMillan Culp, K. (2010). Connecting instructional technology professional development to teacher and student outcomes. Journal of Research on Technology in Education, 43(1), 53.

MinnetonkaSchools. (2011, Feb 10th). iTools: iPads in the Classroom. (Video file). Retrieved from: http://youtu.be/ LWUFXE0OLEW

Moran,M., Hawkes, M., \& Gayar, O. (2010). Tablet personal computer integration in higher education: Applying the unified theory of acceptance and use technology model to understand supporting factors. Journal of Educational Computing Research, 42(1), 79-101.

National Research Council. (2011). Successful K-12 STEM education: Identifying effective approaches in science, technology, engineering, and mathematics. Committee on Highly Successful Science Programs for K-12 Science Education. Board on Science Education and Board on Testing and Assessment, Division of Behavioral and Social Sciences and Education. Washington, DC: The National Academies Press.

National Science Teachers Association (NSTA). (2008). NSTA Position Statement: The Role of E-Learning in Science Education. Retrieved from: http:// www.nsta.org/about/positions/e-learning. aspx.

Perez, O. A., Gonzalez, V., Pitcher, M. T., Golding, P., \& Gomez, H. (2012). Analysis of Mobile Technology impact on STEM based courses: Specifically introduction to engineering in the era of the iPad. The 119th American Society for Engineering Education Annual Conference \& Exposition, San Antonio, Texas. Retrieved from: http://www.asee. org/public/conferences/8/papers/4709/ view.

Reins, K. (2007). Digital tablet PCs as new technologies of writing and learning: A survey of perceptions ofdigital ink technology. Contemporary Issues in Technology and Teacher Education, 7(3), 158-177.

Romney, C. (2011). Tablet PC Use in freshman mathematics classes promotes STEM retention. Presentation at the 41st ASEE/ IEEE Frontiers in Education Conference, Rapid City, SD.

Scott, E. (2012). What it takes to launch a mobile learning program in schools. Retrieved from: http://blogs.kqed.org/ mindshift/2012/07/what-it-takes-tolaunch-a-mobile-learning-program-inschools/.

Smaldino, S. E., Lowther, D. L., \& Russell, J. D. (2012). Instructional technology and media for learning (10th ed.). Boston, MA: Pearson Education

Sikka, P. (April 25, 2014). Why the iPad dominates the US education and enterprise markets. Retrieved from: http://finance. 
yahoo.com/news/why-ipad-dominates-useducation-210040869.html

Stohlmann, M., Moore, T. J., \& Roehrig, G. H. (2012). Considerations for teaching integrated STEM education. Journal of Pre-College Engineering Education Research (J-PEER), 2(1). Retrieved from http://dx.doi. org/10.5703/1288284314653.

The Apple Corporation. (2014). iPad in Education. Retrieved from: https://www. apple.com/education/ipad/apps-booksand-more/.

Thoermer, A., \& Williams, L. (2012).Using digital texts to promote fluent reading. The Reading Teacher, 65(7), 441-445.

UCA STEM Institute. (2013). Mission and vision. Retrieved from: http://uca.edu/ steminstitute/mission-and-vision/

Walker, A., Recker, M., Ye, L., Robertshaw, M. B., Sellers, L., \& Leary, H.(2012). Comparing technology-related teacher professionaldevelopment designs: a multilevel study of teacherand student impacts. Education Technology Research Development, 60, 421-444. doi: 10.1007/ s11423-012-9243-8.

Yin, R. K. (2003).Case study research: Design and methods (3rd ed.). Thousand Oaks: Sage.

\section{Contact the Author}

\section{Haihong $\mathrm{Hu}$}

Assistant Professor, Department of Leadership Studies, College of Education, University of Central Arkansas

Email: hhu@uca.edu

\section{Uma Garimella}

Director, UCA STEM Institute, University of Central Arkansas

Email: ugarimel@uca.edu 